\title{
THE POLICY OF GRANTING REMISSION TO CORRUPTION INMATES IN ORDER TO ERADICATE CORRUPTION IN INDONESIA
}

\author{
M Ali Zaidan \\ Faculty of Law, Universitas Pembangunan Nasional "Veteran” Jakarta \\ E-mail : mali.zaidan@yahoo.co.id
}

\begin{abstract}
Corruption is an extraordinary crime, even though the laws have been revised and has a more progressive character has also established Anti-Corruption Commission the number of crimes of corruption still do not show any significant change. In the midst of public pessimism, the Ministry of Justice and Human Rights has initiated efforts to revise the Government Regulation Number 99 Year 2012. The tightening of remission meant that the convict is not easy to get their sentences reduced. Attempts to revise the provisions concerning remission, it should consider how far can reduce corruption and its impact on inmates and the public.
\end{abstract}

Keywords: extraordinary crime, corruption, remission.

\begin{abstract}
Abstrak
Tindak Pidana Korupsi merupakan kejahatan yang luar biasa, meskipun undang-undang telah dilakukan revisi dan memiliki karakter lebih progresif juga telah dibentuk Komisi Pemberantasan Korupsi, angka kejahatan korupsi tetap tidak memperlihatkan perubahan yang berarti. Di tengah pesismisme publik, Kementerian Hukum dan Hak Asasi Manusia telah menggagas usaha untuk melakukan revisi terhadap Peraturan Pemerintah Nomor 99 Tahun 2012. Pengetatan remisi dimaksudkan agar terpidana tidak dengan mudah untuk mendapatkan pengurangan masa hukuman. Usaha untuk melakukan revisi terhadap ketentuan tentang remisi, harus mempertimbangkan seberapa jauh dapat mengurangi tindak pidana korupsi dan dampaknya terhadap narapidana dan masyarakat.
\end{abstract}

Kata-kata kunci : kejahatan luar biasa, korupsi, remisi.

Introduction

Corruption is no longer a crime that can be considered as an ordinary crime, but a crime that the handling should be carried out in an extraordinary way. ${ }^{1}$ The impacts of corruption affect the economical growth of a country, beside the decreasing of government services quality and adding burdens to the government budget. $^{2}$

Reformation era has a willingness to embody the government to be pure and clean from the corruption, collusion, nepotism. The arrangement of legal substance and legal structure such as renewal of corruption law or the forming

Maryanto, "Pemberantasan Korupsi sebagai Upaya Penegakan Hukum" Jurnal IImiah CIVIS, Volume 2 No. 2 July 2012, Semarang: Universitas PGRI

Amiruddin, "Analisis Pola Pemberantasan Korupsi dalam Pengadaan Barang dan Jasa", Jurnal Kriminologi Indonesia, Vol 8 No. 1, May 2012, Depok: Universitas Indonesia, page 29. of Komisi Pemberantasan Korupsi (KPK) has been settled. Regarding with the aspect of legal culture that has not been changed, this phenomenon is seen from the survey of International Institution which considers Indonesia as a country that still has high corruption level. ${ }^{3}$

The efforts of law enforcement that has been done by KPK or other law firm such as Police and judiciary have reached all state administrators in three state power area or private sector. Along with the law enforcement action, appears a new phenomenon which is the Government plans to give remission toward the corruptor. Policy has been evoked many perceptions

3 Ricca Anggraini, “Pengusungan Pola Pikir Positivisme Hukum dalam Perkara Korupsi (Kajian Putusan Nomor 207 /PID.B/2008/PN.MPW)", Jurnal Yudisial Simulakra Keadilan, Vol. 4 No. 3 December 2011, Jakarta: Komisi Yudisial RI, page 263. 
among the society. Furthermore, the problems that is stated in this writing is how policy about giving remission toward the corruptor has to be lied on the crime prevention frame?

\section{Discussion}

\section{Massive Corruption and Widespread}

Corruption can be defined in common as a criminal offense that harm the society's interest, not only happens in the public sector but also can happen in the private sector. This thing can be caused by the corruption only can be executed by a person or a group of person that have capital and economic power. ${ }^{4}$

Corruption can also be seen from the political aspect, Artidjo Alkostar said that as extra ordinary crimes that is inherent to the power, political corruption in its turn will be turn back and hit the doer itself in term of strike down a regime, leader and political corruptor. Political corruption as predicate crimes tends to bring out its derivative crimes such as human rights violations, restrictions on freedom of the media/ press, persona non grata, political divert attention by performing certain actions that attract public attention despite violating human rights, and other kinds to cover the ongoing corruption. ${ }^{5}$

The antithesis toward the corruption that is really vigorous in one side, has been seen the decadency on the other side. Corruption is regarded as one of main obstacle factor in the implementation of the development in Indonesia. ${ }^{6}$ Every year, Transparency International (TI) always launches Corruption Perception Index (CPI) since1995. According to $\mathrm{TI}$, other country that has same scores with Indonesia is Egypt with 32 scores, on the other hand Albania, Nepal, Vietnam on 32. Ethiopia , Kosovo and Tanzania on the score 33. In the Asia Pacific region, Indonesia is still below Singapore (86), Hong Kong

4 IGM Nurdjana, 2010. Sistem Hukum Pidana dan Bahaya Laten Korupsi, Perspektif Tegaknya Keadilan Melawan Mafia Hukum, Yogyakarta: Pustaka Pelajar, page 42.

5 Artijo Alkostar, "Mengkritisi Fenomena Korupsi di Parlemen", Jurnal Hukum, No. 1 Vol. 15 January 2008, Yogyakarta: Universitas Islam Indonesia, Page 2.

6 Muhammad Fauzan, Bahtaruddin and Hikmah Nuraini, "Implementasi Pemerintahan yang Bersih dalam Kerangka Rencana Aksi Daerah Pemberantasan Korupsi”, Jurnal
(75), Taiwan (61), South Korea (55) and China (40). Indonesia in the ASEAN region under Brunei (60) and Malaysia (50). Filipina (36), Thailand (35). Indonesia is better than Vie-tnam (31), East Timor (30), Laos (26) and Myanmar (21).

The image that is shown shows that Score of Indonesia in CPI 2013 is not increased from score in 2012 that is 32, but Indonesia increased 4 ranks. In the 2012, Indonesia is in the 118 from 176 country and in 2013 is changed into 114 from 177 country. Indonesian scores for 2 years is measured based on the effectiveness of prevention and eradication of corruption. On the other hand, public optimism and success of the Commission in an effort law enforcement give another forms.

The findings of the Global Corruption Barometer (GCB) in 2013 put the parliament and political parties as corrupt institution in the perception and experience of community. Parliament was second most corrupt (after police) of 12 public institutions are assessed. While the political parties were ranked fourth.

Public expectation that is really big that asked for the corruptor is punished severely, as if inversely proportional to the court verdict. One of it is shown with the tendencies of supreme courts in the cassation level that give the verdict that is heavier. The impacts are they that have been verdict by the District Court or High Court tends to receive the verdict in order to avoid the heavier verdict which given by High court of justice.

Pro and contra that is appeared related to the remission given is caused by the low penalties that is given beside the development in the correctional institution has not been effective yet. ${ }^{7}$ The remission given for the corruptor make the corruptor is increasing and not afraid of doing the corruption. ${ }^{8}$ Even, eradication of corruption leads the law firm into tensions for instance

Dinamika Hukum, Vol. 12 No 3 September 2012, Purwokerto: Faculty of Law, Universitas Jenderal Soedirman Purwokerto, page 449.

Barlian Simarmata,"Pemberian Remisi terhadap Narapidana Korupsi dan Teroris" Jurnal Ilmiah Mimbar Hukum, Vol. 23 No. 3 October 2014, Yogyakarta: Faculty of Law, Universitas Gadjahmada, page 504.

8 Dimas Hario Wibowo, "Pelaksanaan Pemberian Remisi terhadap Narapidana Tindak Pidana Korupsi di Lembaga 
such as the tensions between KPK with Indonesian National Police. ${ }^{9}$

Former Secretary General of the United Nations, Kofi Annan ever said that corruption is like the infectious diseases that spread slowly but deadly in the society and create very extensive damage in the society. Corruption can break the democracy and rule of law, and encourage the violation of human rights and distorts the economy. ${ }^{10}$ The pattern of sentencing of a corruptor have been analyzed by Obey Subekti entitled Legal Sanctions for Perpetrators of Corruption: Businesses Looking Raw benchmark for Giving Punishment. According Subekti sentencing used benchmark Minimum Wage a province such as the city A with UMR(regional minimum wage) Rp 900,000 , which is equivalent to one month imprisonment sentence. Stealing a mobile phone worth Rp 2 million, then the calculation is as follows $(2,000,000 / 900,000) \times 1$ month imprisonment $=2$ months 6 days. Likewise, someone with corruption 4 billion rupiahs, then the calculation is as follows: $(4.000 .000 .000 / 900$. 000) $\times 1$ month $=4.444$ month 12 days or 370 years. Those 370 years is certainly fantastic which can be compared with the maximum punishment which is a death penalty or at least long life punishment. ${ }^{11}$

The effort to quantify imprisonment as showed by Taat Subekti can not be used as a standard by the judge in court. The views above are showing that corruption is a crime that carries a big impact for society, and the society must bear the loss. Social and moral damage caused by corruption is an indisputable fact.

Although the remission is a prisoner's rights, but related to corruption, remissions need to be tightened. Tightening remissions as a notification that the state does not compromise to corruption that has made suffering for people.

Pemasyarakatan Kelas I Semarang", Unnes Law Jurnal, Vol. 2 No. 1 June 2013, Semarang: Faculty of Law, Universitas Negeri Semarang, page 13.

9 Bambang Dwi Baskoro, "Perseteruan KPK dengan Polri dalam Upaya Pemberantasan Korupsi”, Jurnal MasalahMasalah Hukum, Vol. 42 No 3 Juli 2013, Semarang: Faculty of Law, Universitas Diponegoro, page 1

10 Ibid.

\section{The Effect of Remission}

Efforts to eradicate corruption by legal institutions and public expectations that corruptor was sentenced to the maximum as though inversely, it is seen from the establishment of the Ministry of Law and Human Rights (Menkumham) Yasonna $\mathrm{H}$ Laoly floated the idea to revise the Government Regulation Number 99 Year 2012 concerning second Amendment to Government Regulation Number 32 Year 1999 concerning the Terms and Procedures for the Implementation of the Rights of Prisoners especially that related with Remission.

The society thinking those idea is not sensitive enough to corruption eradication, therefore it must be rejected. Many suspect that said the idea from Minister of Law and Human Rights (Menkumham) was not consulted and even the President do not want any remissions for the corruptors. ${ }^{12}$ The war for corruption must be always done even though in practice the consolidation among law enforcement agencies is not easy. ${ }^{13}$

Remissions is a means formation in Penitentiary as: a catalyst (for accelerating) an effort to minimize the influence of prisonizati-on; a catalyst (to speed up) giving responsibilities for society; a modification tool for the doer when in the penitentiary; indirectly reduce overcapacity in prisons; and in the framework for the efficiency of the state budget. ${ }^{14}$

Government Regulation Number 99 Year 2012 essentially provides tightening of the remissions, especially for corruption convicts. Remission is only given if the convicted person is willing to be a justice collaborator and has paid fines and restitution that have been determined by the court besides the special requirements that have behaved well and showed signs of remorse during his criminal past.

The application of Government Regulation above should be linked with the purpose of sen-

11 TJ Gunawan, 2015, Konsep Pemindanaan Berbasis Nilai Kerugian Ekonomi, Yogyakarta: Genta Press, page 133.

12 www.koranjakarta.com April 18, 2015 "Obral Remisi terhadap Koruptor" accessed on April 20, 2015.

13 Ibid.

14 Winston Rori, "Kebijakan Hukum mengenai Syarat Pemberian Remisi Kepada Narapidana Tindak Pidana Korupsi", Jurnal Lex Crimen, Vol 2 No. 7 November 2013, Sulawesi Utara: Faculty of Law, Sam Ratulangi, page 28. 
tencing. As known some theories of sentenceing is: the absolutetheory, relative theory and the combined theory, as has been widely known. Other the three theories there is also the fourth theory is called Theory of Contemporary. ${ }^{15}$ The presence of the fourth theory above, according to Eddy OS Hiariej based from the three previous theories with some modifications. Wayne R Lafave is one of the founder the theory. According Lafave one criminal purpose is as a deterrence effect to doer for no longer repeat his actions. ${ }^{16}$

Criminal theories mentioned above is a blend of classical theory based on the principle of let the punishment fit the crime to the modern theory which is based on the philosophy of let the punishment fit the criminal. ${ }^{17}$ In Indonesian contex, crime should be viewed as a disruption of balance and harmony in society. Thus, the purpose of sentencing is to repair the damage of individual and or social. In this case, the purpose of sentencing should be oriented towards an integrative view, which set by the vision of sentencing that must be done, with a note that which goal that casuistic focused with. ${ }^{18}$

All of those theory would be more complete if it is associated with social defense theory which is a new approach to considering the crimes that have serious impacts. One of the concepts that developed in the context of crime prevention is Penal Individualization Principles. This principle is based on the considerations as stated by Sudarto that the penal individualization means to provide criminal sanctions must always pay attention to the properties and the circumstances of the offender. Some characteristics of the penal individualization are: first, accountability (criminal) is personal/ individual (personal principle). People who are guilty of

15 Eddy OS Hiariej, 2014, Prinsip-prinsip Hukum Pidana, Yogyakarta, Cahaya Atma Pustaka, page 35.

16 Ibid.

17 Warih Anjani, "Penjatuhan Pidana Mati di Indonesia dalam Perspektif Hak Asasi Manusia", Jurnal Widya Justisia, Vol. 1 No. 2 March 2015, Jakarta: Widya Kopertis Wilayah 3, page 109-110.

18 Eko Soponyono, "Kebijakan Perumusan Sistem Pemidanaan Yang Berorientasi Pada Korban", Jurnal MasalahMasalah Hukum, Vol. 41 No. 1 January 2012, Semarang: Faculty of Law, Universitas Dipenogoro, page 30. committing a crime should be held responsible for his actions and can not be represented by others. Second, criminal only given to the guilty (culpability principle). The fault both in the form of deliberateness and negligence. Third, criminal should be adjusted with the characteristics and the conditions of the doer. It means there must be looseness/flexibility for the judge to choose criminal sanctions (the type and also the severity of criminal) and there should be a possibility to modify the criminal (changed/ adjusted) in its implementation. ${ }^{19}$

The third characteristic above is the essence in penal individualization concept, including the possibility to give remission given by government. When remission linked to criminal theories, and also criminal prevention, are policies that should be considered carefully given the characteristics attached on the action nor the creator itself (daad en dader strafrecht).

Granting remission to corruptors is giving deterrent effect and prevent the potential of corruption, it is because in Indonesia has developed elitist, endemic and systemic. ${ }^{20}$ The thightening for granting remission also caused by many factors including: first, the requirement of good attitude must be fulfilled by prisoners as a basis for proposing remissions; second, officials authority to evaluate the behaviour of prisoners in penitentiary without proper monitoring has created an opportunity for abusing through deviant behavior; and third, the absence of proper standard set an action categerozied as disciplinary offenses recorded in registration list $F .{ }^{21}$

Based on circular letter of Supreme Court No 4 Year 2011 concerning treatment for Whistleblower and Justice Collaborator (JC) reinforced with a joint decree among LPSK, Attorney General's Office, Police, KPK, and Supreme

19 Tri Wahyu Widiastuti, "Prinsip Individualisasi Pidana dalam Hukum Pidana dan Hukum Pidana Islam di Indonesia", Jurnal Wacana Hukum, Vol. 9 No. 2 September, Surakarta: Universitas Slamet Riyadi, page 46-47

20 Gress Gustia Adriah Pah, "Analisis Yuridis Penjatuhan Pidana oleh Hakim dalam Tindak Pidana Korupsi" (Putusan Nomor 2031/Pid.Sus/2011)", Jurnal Lentera Hukum, Vol 1 No. 1 April 2014, Jember: Faculty of Law, Universitas Jember, page 33.

21 Dani Krisnawati,: “Kajian Yuridis Pemberian Remisi bagi Narapidana”, Jurnal Mimbar Hukum, Vol. 10 No. 2 Juni 2007, Faculty of Law UGM. 
Court. There are several requirements for the JC application in the SEMA. First, only applies on certain criminal crime, serious and/or organized. Second, the doer is not the main doer and admitted their fault. Third, willing to be the witness in the judicial process to expose all who are involved. Fourth, returning all of the assets as a result of the corruption if the assets are on him. ${ }^{22}$

Based on Government Regulation Number 32 Year 1999 has been set strict requirements for example do service to the state, or do anything useful for the country or humanity. The above provisions subsequently revised through Presidential Regulation Number 99 Year 2012 which determines among other things: well-behaved; and have undergone criminal past of more than 6 months.

It can be argued that the provision was addressed to all the inmates or children inmates who are serving a sentence at the Correctional Institution. However, for certain crimes should be given a separate regulation, especially corruption. It is expressly stated in Article 34 A point $a$ and point $b$ Government Regulation Number 99 Year 2012. First, willing to cooperate with law enforcement to help expose the criminal case they did. Second, has been fully paid the fines and restitution according to the court decision for inmates who had been convicted of corruption.

Granting remission to corruptor has a spesific requirements ie cooperate with the law enforcement to expose a bigger corruption cases. This requirement should be strict in acts of the actors are low-level participants in that criminal case, for example as a helper (medeplictigeheid) not as a participant in terms of medeplegeror mededader.

Beside the strict requirements to become $\mathrm{JC}$ the provision also requires that the actor

22 Nixon dkk, "Perlindungan Hukum Terhadap Whistleblower dan Justice Collaborator dalam Upaya Pemberantasan Tindak Pidana Korupsi”, USU Law Journal, Vol. 2 No. 2 November 2013, Medan: Faculty of Law, Universitas Sumatera Utara, page 48-49

23 La Sina, "Dampak dan Upaya Pemberantasan Korupsi Serta Pengawasan Korupsi di Indonesia", Jurnal Hukum Pro Justicia, Vol 26 No. 1 January 2008, Bandung: Faculty of Law, Universitas Parahyangan, page 39. must pay off fines and payment of restitution as a result of doing corruption. ${ }^{23}$ In condemnation of corruption, corporal punishment is seen to be a subsidiary, which is preferably to recover losses caused as a result of criminal act. The mechanism of returning state losses can be done with civil forfeture procedure through lawsuit in rem, a lawsuit that the substance is an appropriation of wealth to corruption civilly with the restoration of state wealth that has been corrupted. ${ }^{24}$

To close this section, the writer expressed a view from Eman Suparman that as an extraordinary crime, there must be a sentencing will cause a deterrent effect towards the doer. So, he assessed granting remission and parole could be implicated by the recurrence of similar crimes. ${ }^{25}$ Remissions policy against corruption convicts, if it is not done strictly will have some impact oneradicating corruption efforts, particularly deterrent effect caused. Remissions which is conducted arbitrarily is a form of injustice which is counter productive to the eradication of corruption in order to create a clean government.

\section{Conclusion}

Based on the research, it can be concluded that: first, corruption should be seen as systemic crime and has serious impact which has to overcome it in an extraordinary way; second, granting remission should be put in the context of overall crime prevention in order to eradicate the corruption to be effective, in order to create clean government.

\section{Recommendations}

First, enforcement law of eradicate the corruptionshould continue to be intensified, any one who commits a crime, they should be punished the deprivation of liberty, also criminal

24 Mahmud Mulyadi, "Penanggulangan Tindak Pidana Korupsi dalam Perspektif Criminal Policy", Jurnal Legislasi Indonesia, Vol 8 June 2011, Jakarta: Kemenkum HAM RI. page 234.

25 WWW.republika/co.id. "KY Tolak Remisi untuk Koruptor"Thursday, March 12, 2015, accessed on March 15, 201517:47 WIB 
compensation should not be replaced by imprisonment. Second, granting remission of corruption must consider the aspect of prevention and control of corruption eradication

\section{References}

Alkostar, Artijo. "Mengkritisi Fenomena Korupsi di Parlemen". Jurnal Hukum, No. 1 Vol. 15 January 2008. Yogyakarta: Universitas Islam Indonesia Yogyakarta;

Amiruddin. "Analisis Pola Pemberantasan Korupsi dalam Pengadaan Barang dan Jasa". Jurnal Kriminologi Indonesia, Vol 8 No. 1. May 2012. Depok :Universitas Indone-sia;

Anggraini, Ricca. "Pengusungan Pola Pikir Positivisme Hukum dalam Perkara Korupsi (Kajian Putusan Nomor 207./PID.B/2008/ PN.MPW)". Jurnal Yudisial Simulakra Keadilan, Vol. 4 No. 3 December 2011. Jakarta : Komisi Yudisial RI;

Anjani, Warih. "Penjatuhan Pidana Mati di Indonesia dalam Perspektif Hak Asasi Manusia”. Jurnal Widya Justisia, Vol. 1 No. 2 March 2015. Jakarta: Widya Kopertis Wilayah 3;

Baskoro, Bambang Dwi. "Perseteruan KPK dengan Polri dalam Upaya Pemberantasan Korupsi”. Jurnal Masalah-Masalah Hukum, Vol. 42 No 3 Juli 2013 . Semarang: Faculty of Law, Universitas Diponegoro;

Fauzan, Muhammad, Bahtaruddin \& Hikmah Nuraini. "Implementasi Pemerintahan yang Bersih dalam Kerangka Rencana Aksi Daerah Pemberantasan Korupsi”. Jurnal Dinamika Hukum, Vol 12 No 3 September 2012. Purwokerto: Fakultas Hukum Universitas Jenderal Soedirman Purwokerto;

Gunawan, TJ. 2015. Konsep Pemindanaan Berbasis Nilai Kerugian Ekonomi. Yogyakarta: Genta Press;

Hiariej, Eddy OS. 2014. Prinsip-prinsip Hukum Pidana. Yogyakarta. Cahaya Atma Pustaka;

Krisnawati, Dani. "Kajian Yuridis Pemberian Remisi bagi Narapidana". Jurnal Mimbar Hukum, Vol. 10 No. 2 Juni 2007. Faculty of Law UGM;

Maryanto. "Pemberantasan Korupsi sebagai Upaya Penegakan Hukum". Jurnal IImiah ClVIS. Vol. 2 No. 2 July 2012. Semarang: Universitas PGRI;
Mulyadi, Mahmud. "Penanggulangan Tindak Pidana Korupsi dalam Perspektif Criminal Policy”. Jurnal Legislasi Indonesia, Vol 8 June 2011. Jakarta: Kemenkum HAM RI;

Nixon, dkk. "Perlindungan Hukum terhadap Whistleblower dan Justice Collaborator dalam Upaya Pemberantasan Tindak Pidana Korupsi”. USU Law Journal, Vol. 2 No. 2 November 2013. Medan: Fakultas Hukum Universitas Sumatera Utara;

Nurdjana, IGM. 2010. Sistem Hukum Pidana dan Bahaya Laten Korupsi. Perspektif Tegaknya Keadilan Melawan Mafia Hukum. Yogyakarta: Pustaka Pelajar;

Pah, Gress Gustia Adriah. "Analisis Yuridis Penjatuhan Pidana oleh Hakim dalam Tindak Pidana Korupsi (Putusan Nomor 2031/ Pid.Sus/2011)". Jurnal Lentera Hukum, Vol. 1 No. 1 April 2014. Jember : Fakultas Hukum Universitas Jember;

Rori, Winston. "Kebijakan Hukum mengenai Syarat Pemberian Remisi Kepada Narapidana Tindak Pidana Korupsi”. Jurnal Lex Crimen. Vol 2 No. 7 November 2013. Sulawesi Utara: Fakultas Hukum Sam Ratulangi;

Simarmata, Barlian. "Pemberian Remisi terhadap Narapidana Korupsi dan Teroris". Jurnal Ilmiah Mimbar Hukum, Vol. 23 No. 3 October 2014. Yogyakarta: Fakultas Hukum Universitas Gadjahmada;

Sina, La. "Dampak dan Upaya Pemberantasan Korupsi Serta Pengawasan Korupsi di Indonesia”. Jurnal Hukum Pro Justisia, Vol 26 No. 1 January 2008. Bandung: Fakulas Hukum Universitas Parahyangan;

Soponyono, Eko. "Kebijakan Perumusan Sistem Pemidanaan yang Berorientasi Pada Korban". Jurnal Masalah-Masalah Hukum, Vol 41 No. 1 January 2012. Semarang: Faculty of Law, Universitas Dipenogoro;

Wibowo, Dimas Hario. "Pelaksanaan Pemberian Remisi terhadap Narapidana Tindak Pidana Korupsi di Lembaga Pemasyarakatan Kelas I Semarang". Unnes Law Jurnal, Vol. 2 No. 1 June 2013. Semarang: Fakultas Hukum Universitas Negeri Semarang;

Widiastuti, Tri Wahyu. "Prinsip Individualisasi Pidana Dalam Hukum Pidana Dan Hukum Pidana Islam Di Indonesia". Jurnal Wacana Hukum. Vol. 9 No. 2 September. Surakarta: Universitas Slamet Riyadi; 